\title{
Laccase Activities from Three White-rot Fungal Species Isolated from Their Native Habitat in North China Using Solid-State Fermentation with Lignocellulosic Biomass
}

\author{
Wan-Xin Liu, ${ }^{\text {a }}$ Meng-Yao Zhao, ${ }^{\text {a }}$ Mei-Xue Li, ${ }^{\text {a }}$ Xue-Qing Li, ${ }^{\text {a }}$ Tian-Xin Zhang, \\ Xi Chen, ${ }^{a}$ Xun-You Yan, ${ }^{\text {a,b,c }}$ Lu-Sen Bian,,${ }^{\mathrm{e}}$ Qi An, ${ }^{\mathrm{a}, \mathrm{b}, \mathrm{c}}$ Wen-Jing Li, ${ }^{\mathrm{a}}$ and \\ Mei-Ling Han ${ }^{\text {a,b,c,d,* }}$
}

\begin{abstract}
Laccase has huge potential application in all aspects of biotechnology due to the ability of laccase to oxidize a wide range of phenolic and nonphenolic compounds. The future success of such applications requires large amounts of laccase with low costs. White-rot fungi are important groups of laccase production. In this study, three white-rot fungi, Phlebia acerina Han 618, Trametes hirsuta Han 726, and Coriolopsis trogii Han 751, isolated from a native North China habitat, were identified by the method of molecular biology and preliminary screening of the ability of laccase-production by guaiacol selection medium. Then they were fermented on different lignocellulosic biomass. Three species showed consistency in preference of lignocellulosic biomass, and the presence of stalk of Sorghum bicolor was more suitable for secreting laccase. The capacity of laccase secretion from different species was significantly different. The capacity of secreting laccase of $C$. trogii Han 751 was superior to that of $P$. acerina Han 618 and T. hirsuta Han 726. The discovery of a new strain with superior capacity of secreting laccase and suitable lignocellulosic biomass were helpful for laying a foundation for the optimization of the fermentation conditions for the highest laccase production, the isolation and purification of laccase, and the industrial application of laccase.
\end{abstract}

DOI: 10.15376/biores.17.1.1533-1550

Keywords: Laccase activity; Coriolopsis trogii; Trametes hirsuta; Phlebia acerina; Solid-state fermentation; Lignocellulosic biomass

Contact information: a: College of Life Science, Langfang Normal University, Langfang 065000, Hebei, China; b: Technical Innovation Center for Utilization of Edible and Medicinal Fungi in Hebei Province, Langfang 065000, Hebei, China; c: Edible and Medicinal Fungi Research and Development Center of Universities/Colleges in Hebei Province, Langfang 065000, Hebei, China; d: Forestry Engineering and Biodiversity Conservation Technology Research and Development Center in Langfang City, Langfang 065000, Hebei, China; e: Experimental Centre of Forestry in North China, Chinese Academy of Forestry, Beijing 102300, China; * Corresponding author: meilinghan309@163.com

\section{INTRODUCTION}

With the rapid economic development and the rapid increase in population, the human energy demand and energy consumption is increasing (Li et al. 2021; Yousef et al. 2021a, 2021b). Fossil energy is irreplaceable and finite, and the pollutants released during the combustion process of fossil energy cause serious pollution to the environment (Moreira et al. 2016; Darwesh et al. 2020). Lignocellulosic biomass, as the most abundant and cheapest renewable eco-friendly resource on Earth, is usually disposed of in a simple 
and crude way, such as burning it or piling it up to rot, causing serious air pollution. Meanwhile, lignocellulosic biomass has attracted increasing attention due to its ability to be converted into other types of products, such as bioenergy and other chemicals (An et al. 2020, 2021; Atilano-Camino et al. 2020; Gaikwad and Meshram 2020; Han et al. 2021a). Producing enzymes with lignocellulosic biomass through the method of solid-state or submerged fermentation has been widely accepted by researchers. Among the enzymes, laccase is one of the oldest enzymes and has been studied extensively by researchers all over the world.

Laccase (EC 1.10.3.2), belonging to blue multi-copper oxidase, was first found in Rhus vernicifera and is widely distributed in various higher plants, some insects, fungi, and bacteria (Zhang et al. 2020; Han et al. 2021c). Based on its ability to oxidize various kinds of phenolic and non-phenolic compounds, laccase has huge potential application in all aspects of biotechnology involving materials science, biodegradation, bioremediation, drug analysis, biosensor, nanobiotechnology, the paper and pulp industry, food chemistry, and biofuels (Unuofin et al. 2019; Zerva et al. 2019; Huang et al. 2020; Coria-Oriundo et al. 2021; Shokri et al. 2021; Sun et al. 2021a, 2021b; Zhou et al. 2021). Furthermore, laccase plays an important role in lignin degradation, fruiting body formation, and plant pathogenesis (Janusz et al. 2015; An et al. 2018). Laccase is secreted mainly by bacteria and fungi. Among all types of fungi, white-rot fungi are recognized as excellent laccase producers. Meanwhile, the prerequisites of the above wide application of laccase are the availability of a large number of low-cost laccases. Unfortunately, laccase secreted by common wild or cultivated fungi under simple fermentation conditions has the characteristics of low yield, weak activity, and low economic benefit, so it is not suitable for commercial, large-scale application (Rodrigues et al. 2019; An et al. 2021). On this basis, the development of new laccase producing strains and the selection of low-cost lignocellulosic biomass used for fermentation could be helpful for opening new opportunities in aspects of commercial and industrial applications (Huang et al. 2019; An et al. 2020).

Laccase secreted by fungi could be affected by many factors, including $\mathrm{pH}$, temperature, secondary metabolites and category, co-culture of fungi, concentration, and proportion of carbon and nitrogen sources, metal ions (An et al. 2016; Ottoni et al. 2016; Bettin et al. 2019; Yin et al. 2019; Han et al. 2021a; Hu et al. 2021). Similarly, fermentation method is also an important factor to fungi secreting laccase (Sharma et al. 2019; An et al. 2021). The main advantage of submerged fermentation ( $\mathrm{SmF})$ is that it is easy to control the fermentation conditions; thus it is more suitable for industry producing laccase. But there is no denying that the enzymes are diluted during the process of submerged fermentation, and solid-state fermentation (SSF) avoids the dilution of the enzyme. Furthermore, the process of solid-state fermentation is more similar to the environment in which fungi are living in in their natural habitat (Steudler and Bley 2015). In recent years, the solid-state fermentation method has attracted a great deal of attention in producing enzymes, especially laccase (Soccol et al. 2017). Lignocellulosic biomass is the main material used in solid-state fermentation for fungi grown and the types of lignocellulosic biomass used in previous studies were mainly tree leaves, sugar cane bagasse, coffee shell, and corncob. Previous studies had indicated that the difference in the production of laccase secreted by fungi was noticeable (An et al. 2020, 2021). Thus, developing new producing laccase fungi species is very meaningful and essential work.

Presently, related studies on laccase are mainly focused on a few genera, such as Pleurotus, Flammulina, Ganoderma, Trametes, Lentinus, and Phanerochaete (Elisashvili 
et al. 2008; Huang et al. 2019; An et al. 2020, 2021; Atilano-Camino et al. 2020). Of course, new studies have begun to develop new productive strains and evaluate their capacity of secreting laccase (Han et al. 2021a, 2021c). Very few studies have considered using more numbers of lignocellulosic biomass for grown fungi to produce laccase. However, it is important to develop new laccase producing fungi and screen suitable lignocellulosic biomass to produce laccase. Under the circumstances, three white-rot fungal species, Han 618, Han 726, and Han 751, isolated from their native habitat in North China, were used to evaluate their capacities of secreting laccase under solid-state fermentation with six lignocellulosic biomasses (stalk of Helianthus annuus, stalk of Sorghum bicolor, Pinus tabuliformis, Populus beijingensis, cottonseed hull, and corncob). The results were helpful for screening a new strain and suitable lignocellulosic biomass, and also laid a foundation for the optimization of the fermentation conditions for laccase production, the isolation and purification of laccase, and the industrial application of laccase.

\section{EXPERIMENTAL}

\section{Materials}

Microorganisms and chemicals

Three white-rot fungi, Han 618, Han 726, and Han 751, used in the present study were collected from Maojingba National Nature Reserve (Chengde City, Hebei Province, China) and were isolated on malt extract agar (MEA) medium (glucose $10 \mathrm{~g}$, malt extract $20 \mathrm{~g}, \mathrm{KH}_{2} \mathrm{PO}_{4} 3 \mathrm{~g}$, agar $18 \mathrm{~g}$, and deionized water $1 \mathrm{~L}$ ) and purified on CYM medium (glucose $20 \mathrm{~g}$, peptone $2 \mathrm{~g}$, yeast extract $2 \mathrm{~g}, \mathrm{MgSO}_{4} \cdot 7 \mathrm{H}_{2} \mathrm{O} 0.5 \mathrm{~g}, \mathrm{~K}_{2} \mathrm{HPO}_{4} \cdot 3 \mathrm{H}_{2} \mathrm{O} 1 \mathrm{~g}$, $\mathrm{KH}_{2} \mathrm{PO}_{4} 0.46 \mathrm{~g}$, agar $15 \mathrm{~g}$, and deionized water $1 \mathrm{~L}$ ). All microorganisms were maintained at the College of Life Science of Langfang Normal University.

All basal chemicals were purchased from Tianjin Zhiyuan Chemical Reagent Co. Ltd. (Tianjin, China). Malt extract, yeast extract, and peptone were purchased from Beijing Aobo Star Biotechnology Co. Ltd. (Beijing, China). Agar and 2,2'-azinobis-[3ethyltiazoline-6-sulfonate] (ABTS) were purchased from Beijing BioDee Bio. Tech. Co. Ltd. (Beijing, China) and Sigma Aldrich Trading Co., Ltd. (Shanghai, China), respectively.

\section{Lignocellulosic biomass}

The lignocellulosic biomasses used were the stalk of Helianthus annuus (SOHA), stalk of Sorghum bicolor (SOSB), Pinus tabuliformis, Populus beijingensis, cottonseed hull, and corncob. Among them, H. annuus, stalk of S. bicolor, P. tabuliformis, cottonseed hull, and corncob were kindly provided by farmers from Chengde City (Hebei Province, China). Populus beijingensis was obtained from Langfang City (Hebei Province, China). All lignocellulosic biomasses were air-dried and milled with the particle size between 20and 60-mesh.

\section{Methods}

Fungal culture and screening for laccase-producing fungi

Three white-rot fungi were grown on CYM medium for 8 days at $26{ }^{\circ} \mathrm{C}$ to perform the activation. Each fungal isolate $(5 \mathrm{~mm}$ agar disc) was punched by a hole punch on the activated Petri dishes and transferred to guaiacol selection medium (guaiacol $1 \mathrm{~g}$, ammonium tartrate $0.1 \mathrm{~g}$, peptone $2.6 \mathrm{~g}, \mathrm{MgSO}_{4} \cdot 7 \mathrm{H}_{2} \mathrm{O} 0.5 \mathrm{~g}, \mathrm{KH}_{2} \mathrm{PO}_{4} 1 \mathrm{~g}, \mathrm{Na}_{2} \mathrm{HPO}_{4} 0.2 \mathrm{~g}$, agar $18 \mathrm{~g}$, and deionized water $1 \mathrm{~L}$ ) for 10 days at $26^{\circ} \mathrm{C}$. 


\section{Inoculum preparation}

Five fungal isolate ( $5 \mathrm{~mm}$ agar disc) were added into $250-\mathrm{mL}$ flasks containing 100 $\mathrm{mL}$ CYM liquid medium and cultured under oscillating conditions with $150 \mathrm{rpm}$ at $26{ }^{\circ} \mathrm{C}$. After 8 days, the mycelium pellets were homogenized with a modular homogenizer S10 (Ningbo Xinzhi Biotechnology Co., Ltd., Zhejiang, China) at 8,000 rpm for $2 \mathrm{~min}$ and the homogenized liquid was used as an inoculum.

\section{Laccase-producing by fungi on solid-state fermentation}

Erlenmeyer flasks $(250 \mathrm{ml})$ containing $2 \mathrm{~g}$ lignocellulosic biomass were moistened with $8 \mathrm{~mL}$ of basal solution and autoclaved at $121{ }^{\circ} \mathrm{C}$ for $30 \mathrm{~min}$. The components of the basal solution were as follows: $\mathrm{MgSO}_{4} \cdot 7 \mathrm{H}_{2} \mathrm{O} 0.5 \mathrm{~g} / \mathrm{L}, \mathrm{K}_{2} \mathrm{HPO}_{4} \cdot 3 \mathrm{H}_{2} \mathrm{O} 1 \mathrm{~g} / \mathrm{L}$, and $\mathrm{KH}_{2} \mathrm{PO}_{4}$ $0.46 \mathrm{~g} / \mathrm{L}$. After sterilizing, each Erlenmeyer flasks was added to $3 \mathrm{~mL}$ of homogenized inoculum. Then, all flasks were transferred to a constant temperature incubator $\left(26{ }^{\circ} \mathrm{C}\right)$, and the whole fermentation process was performed.

\section{Preparation of crude enzyme}

To obtain the crude enzyme, the flasks with fermentation lignocellulosic biomass were suspended in a $100 \mathrm{~mL}$ acetate-sodium acetate buffer $(50 \mathrm{mM}, \mathrm{pH} 5.5)$, extracted on a rotary shaker at $10{ }^{\circ} \mathrm{C}$ with a speed of $120 \mathrm{rpm}$ for $4 \mathrm{~h}$ (An et al. 2021), and filtered through a filter paper. The filtrate was centrifuged at $4{ }^{\circ} \mathrm{C}(12,000 \mathrm{rpm}, 20 \mathrm{~min})$, and the supernatant was used for the determination of laccase activity.

\section{Determination of laccase activity}

Laccase activity was assayed by the method of ABTS (2,2'-azinobis-[3ethyltiazoline-6-sulfonate]) (Han et al. 2021a,c). The ABTS was used as substrate, and the reaction system was detected using an iMark ${ }^{\mathrm{TM}}$ microplate absorbance reader (Bio-Rad, Hercules, CA, USA). The reaction mixture contained $190 \mu \mathrm{L}$ acetate-sodium acetate buffer (50 mM, pH 4.2), $100 \mu \mathrm{L}$ ABTS, and $10 \mu \mathrm{L}$ crude enzyme. One unit of laccase activity was defined as the amount of crude enzyme required to oxidize $1 \mu \mathrm{mol}$ of ABTS per min $\left(\varepsilon_{415}=3.16 \times 10^{4} \mathrm{M}^{-1} \mathrm{~cm}^{-1}\right)$.

\section{Statistical analysis}

All data were expressed as the mean value \pm standard deviation (SD) $(n=3)$. The obvious differences were calculated by ANOVA (analysis of variance) using SPSS software version 22.0 (PROC GLM, IBM SPSS software version 22.0, Armonk, NY, USA). Statistical figures were generated by the Origin software version 2016 (OriginLab Corporation, Northampton, MA, USA).

\section{Identification of the selected fungal strain}

The potential laccase-producing fungal strain was identified based on the sequence of internal transcribed spacer (ITS). The strain was grown on CYM medium for 8 days, and the cultivated microorganism was scraped by a clean surgical blade from the surface of the Petri dishes. The total genomic DNA was extracted using the cetyltrimethylammonium bromide (CTAB) rapid plant genome extraction kit-DN14 (Aidlab Biotechnologies Co., Ltd., Beijing, China) (Han et al. 2016, 2020a, 2021b). The ITS (internal transcribed spacer) region of white-rot fungi was used by general sequence ITS5 (5'-GGAAGTAAAAGTCGTAACAAGG-3') and ITS4 (5'-TCCTCCGCTTATTGATATGC-3') (White et al. 1990). After amplification, the PCR products were purified and 
sequenced at Beijing Genomics Institute (Beijing, China), and the newly generated sequences were deposited at GenBank. Maximum parsimony phylogenetic analysis was performed in PAUP* version 4.0b10 (Swofford 2002) and followed the operational process described by Han et al. (2016). Branch support was determined by 1000 bootstrap replicates (Felsenstein 1985).

\section{RESULTS AND DISCUSSION}

\section{Screening the Laccase-Producing Fungi Isolate}

Research on laccase from white-rot fungi has mainly been focused on a few genera, such as Pleurotus, Flammulina, Ganoderma, Trametes, Lentinus, and Phanerochaete (Elisashvili et al. 2008; Huang et al. 2019; An et al. 2020, 2021; Atilano-Camino et al. 2020). However, the development of new strains that have the capacity of producing laccase is extremely important. On the other hand, the difference in degradation efficiency of lignin, the type and activity of the enzyme, and requirements for environmental conditions was huge due to different strains belonging to different species or different genus. Therefore, it is of great practical significance to isolate and obtain more abundant white-rot fungi strains from the native habitat and screen for laccase-producing fungi. Thus, three white-rot fungi were isolated from their native habitat in North China for the aim to evaluate the capacity of secreting laccase. Three white-rot fungi, Phlebia acerina Han 618, Trametes hirsuta Han 726, and Coriolopsis trogii Han 751, showed discoloration by screening with guaiacol selective medium. As shown in Table 1, three white-rot fungi showed discoloration on guaiacol selective medium and the ratio of colony diameters (d1) to photochramic laps $(\mathrm{d} 2)$ was less than $1(\mathrm{~d} 1 / \mathrm{d} 2<1)$. The ratio of colony diameters to photochramic laps of Han 618, Han 726, and Han 751 was 0.83, 0.21, and 0.40 (Table 1). Microorganisms with discoloration on guaiacol selective medium indicate that the microorganisms have the ability to degrade lignin (Nishida et al. 1988). Thus, all tested white-rot fungi were shown to have the ability to degrade lignin.

Table 1. Discoloration Results of Three White-Rot Fungi on Selected Medium

\begin{tabular}{|c|c|c|c|}
\hline White-rot Fungi & Colony Diameters $\mathrm{d} 1(\mathrm{~cm})$ & Photochramic Laps d2 $(\mathrm{cm})$ & $\mathrm{d} 1 / \mathrm{d} 2$ \\
\hline Han 618 & 4.4 & 5.3 & 0.83 \\
\hline Han 726 & 0.8 & 3.8 & 0.21 \\
\hline Han 751 & 1.9 & 4.8 & 0.40 \\
\hline
\end{tabular}

\section{Identification of the Selected Laccase-Producing Fungal Strain}

The MW547892, MZ413707, and MZ413708 are GenBank numbers of newly generated ITS sequences for the three laccase-producing fungal strains Han 751, Han 726, and Han 618, respectively. In the ITS phylogenetic tree, the strain Han 751 was grouped with two samples of Coriolopsis trogii (Berk.) Domański, the strain Han 726 was grouped with three samples of Trametes hirsuta (Wulfen) Lloyd, and the strain Han 618 was clustered with three samples of Phlebia acerina Peck (Fig. 1). Thus, the strains Han 751, Han 726, and Han 618 were identified as Coriolopsis trogii, Trametes hirsute, and Phlebia acerina, respectively. 


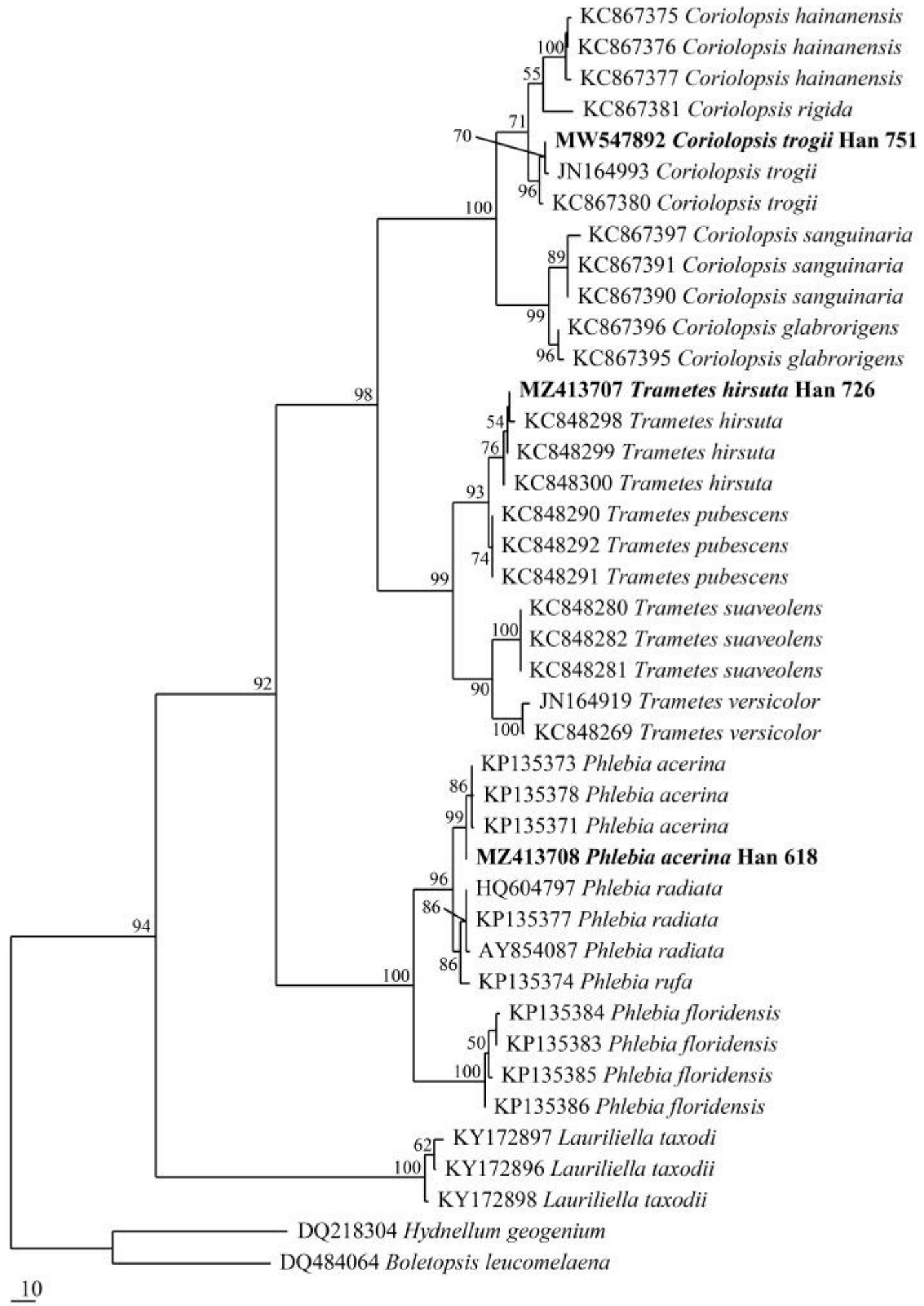

Fig. 1. Maximum parsimony strict consensus tree illustrating the phylogeny of three white-rot fungal strains based on ITS sequences. Branches are labeled with parsimony bootstrap proportions $\geq 50 \%$. 


\section{Statistical Analysis Results}

The effects of species and lignocellulosic biomass on laccase activity were significant $(\mathrm{P}<0.001)$ at different fermentation times (Table 2). Similarly, the interaction of species and lignocellulosic biomass on laccase activity was significant at different fermentation times $(\mathrm{P}<0.001)$ (Table 2).

Table 2. Effects of Species, Lignocellulosic Biomass, and the Interactions of Species and Lignocellulosic Biomass on Laccase Activity (Two-way ANOVA)

\begin{tabular}{|c|c|c|c|}
\hline Incubation Period (d) & Species & $\begin{array}{l}\text { Lignocellulosic } \\
\text { Biomass }\end{array}$ & $\begin{array}{c}\text { Species } \times \text { Lignocellulosic } \\
\text { Biomass }\end{array}$ \\
\hline 1 & $580.063^{\star * *}$ & $504.009^{* \star *}$ & $648.398^{\star \star *}$ \\
\hline 2 & $735.058^{\star \star \star}$ & $303.308^{\star * *}$ & $342.138^{\star * *}$ \\
\hline 3 & $1423.847^{* \star *}$ & $308.847^{* \star *}$ & $720.647^{* \star *}$ \\
\hline 4 & $418.315^{\star \star \star}$ & $394.285^{\star \star \star}$ & $401.622^{* \star *}$ \\
\hline 5 & $1693.379^{\star \star \star}$ & $2398.408^{\star * \star}$ & $1839.419^{\star \star \star}$ \\
\hline 6 & $292.894^{\star \star \star}$ & $760.048^{\star \star \star}$ & $330.429^{\star \star \star}$ \\
\hline 7 & $1148.417^{\star \star *}$ & $2311.367^{* * *}$ & $1035.541^{* * *}$ \\
\hline 8 & $380.293^{\star * *}$ & $968.723^{* \star *}$ & $198.423^{\star * *}$ \\
\hline 9 & $1329.299^{\star \star *}$ & $1238.833^{\star * *}$ & $958.366^{\star \star *}$ \\
\hline 10 & $1113.058^{\star \star *}$ & $2879.468^{\star * \star}$ & $876.494^{* \star *}$ \\
\hline \multicolumn{4}{|c|}{${ }^{\star}$ Note: $\mathrm{df}=2,5,10 ;{ }^{\star \star \star} \mathrm{P}<0.001$} \\
\hline
\end{tabular}

Laccase Activity from Phlebia acerina Han 618, Trametes hirsuta Han 726, and Coriolopsis trogii Han 751 on Different Lignocellulosic Biomass

Recent studies have indicated that the presence of lignocellulosic biomass could stimulate laccase production by basidiomycetes (Birhanli and Yeşilada 2013; Zhou et al. 2014; Palazzolo et al. 2019; An et al. 2020, 2021; Han et al. 2021a, 2021c). Meanwhile, the selection of appropriate lignocellulosic biomass for fungus growth and enzyme production plays an important role in the development of efficient biotechnology (Elisashvili et al. 2008; Han et al. 2021a). There have been few studies on laccase related to the genus Phlebia, and previous studies were mainly focused on the effect of chemical and metallic compounds on laccase or the heterologous expression of a laccase gene (Kaneko et al. 2009; Fonseca et al. 2014, 2018; Janusz et al. 2016). However, the effect of lignocellulosic biomass on laccase activity from the genus Phlebia has not been reported. The laccase of genus Trametes has been extensively studied, and Trametes hirsuta Han 726 used in this study also belongs to one species of genus Trametes (KołodziejczakRadzimska et al. 2020; Sun et al. 2020; Bilal et al. 2021; Mejía-Otálvaro et al. 2021; Navada and Kulal 2021; Wulandari et al. 2021; Zhang et al. 2021). However, the laccase of genus Coriolopsis has been less studied, and previous studies were mainly focused on recombinant expression, heterologous expression, and the selection of high production of laccase (Songulashvili et al. 2016; Xu et al. 2016; Avelar et al. 2017; Pinar et al. 2017; Glazunova et al. 2018). Additionally, lignocellulosic biomass used in previous studies merely related to laccase from genus Coriolopsis were chestnut shell and barley bran. According to the above mentioned, there are few studies on the effects of lignocellulosic biomass on genus Phlebia, Trametes, and Coriolopsis. 
The value of laccase activity from Phlebia acerina Han 618 on SOHA, SOSB, Pinus tabuliformis, Populus beijingensis, cottonseed hull, and corncob was 0 U/L, 0 U/L, $0 \mathrm{U} / \mathrm{L}, 1.51 \pm 0 \mathrm{U} / \mathrm{L}, 1.51 \pm 0 \mathrm{U} / \mathrm{L}$, and $0 \mathrm{U} / \mathrm{L}$ on the $1^{\text {st }}$ day, respectively. The first time laccase activity was detected on stalk of Helianthus annuus (SOHA) was on the $6^{\text {th }}$ day, and the value of laccase activity was $0.60 \pm 0 \mathrm{U} / \mathrm{L}$. The maximum laccase activity from SOHA was $18.98 \pm 1.81 \mathrm{U} / \mathrm{L}$ on $7^{\text {th }}$ day (Table 3, Fig. 2). The trend of laccase activity on SOSB was similar to the trend from SOHA, and laccase activity $(6.63 \pm 0.60 \mathrm{U} / \mathrm{L})$ was detected on the $5^{\text {th }}$ day for the first time (Fig. 2). The maximum laccase activity from SOSB was $110.21 \pm 1.82 \mathrm{U} / \mathrm{L}$ on $10^{\text {th }}$ day (Table 3, Fig. 2). Laccase activity from Pinus tabuliformis and corncob was detected only on one day (the $6^{\text {th }}$ day and $5^{\text {th }}$ day) and was very low $(4.62 \pm 0.46 \mathrm{U} / \mathrm{L}$ and $1.51 \pm 0 \mathrm{U} / \mathrm{L})$, respectively. The trend of laccase activity on Populus beijingensis was different from that of other lignocellulosic biomass in that the laccase activity reached its maximum values $(7.43 \pm 0.35 \mathrm{U} / \mathrm{L})$ on the $3^{\text {rd }}$ day but remained low throughout the whole stage of fermentation (Fig. 2). The laccase activity on cottonseed hull showed a small peak $(15.47 \pm 1.55 \mathrm{U} / \mathrm{L})$ on the $4^{\text {th }}$ day and reached the maximum value $(28.03 \pm 1.88 \mathrm{U} / \mathrm{L})$ on the $9^{\text {th }}$ day (Table 3$)$. Obviously, the maximum laccase activity from $P$. acerina Han 618 was $110.21 \pm 1.82 \mathrm{U} / \mathrm{L}$ on SOSB, nearly 5.81-fold, 23.85-fold, 14.83-fold, 3.93-fold, and 72.99-fold, higher than that on SOHA, Pinus tabuliformis, Populus beijingensis, cottonseed hull, and corncob, respectively. Additionally, SOSB was more suitable for $P$. acerina Han 618 with respect to secreting laccase.

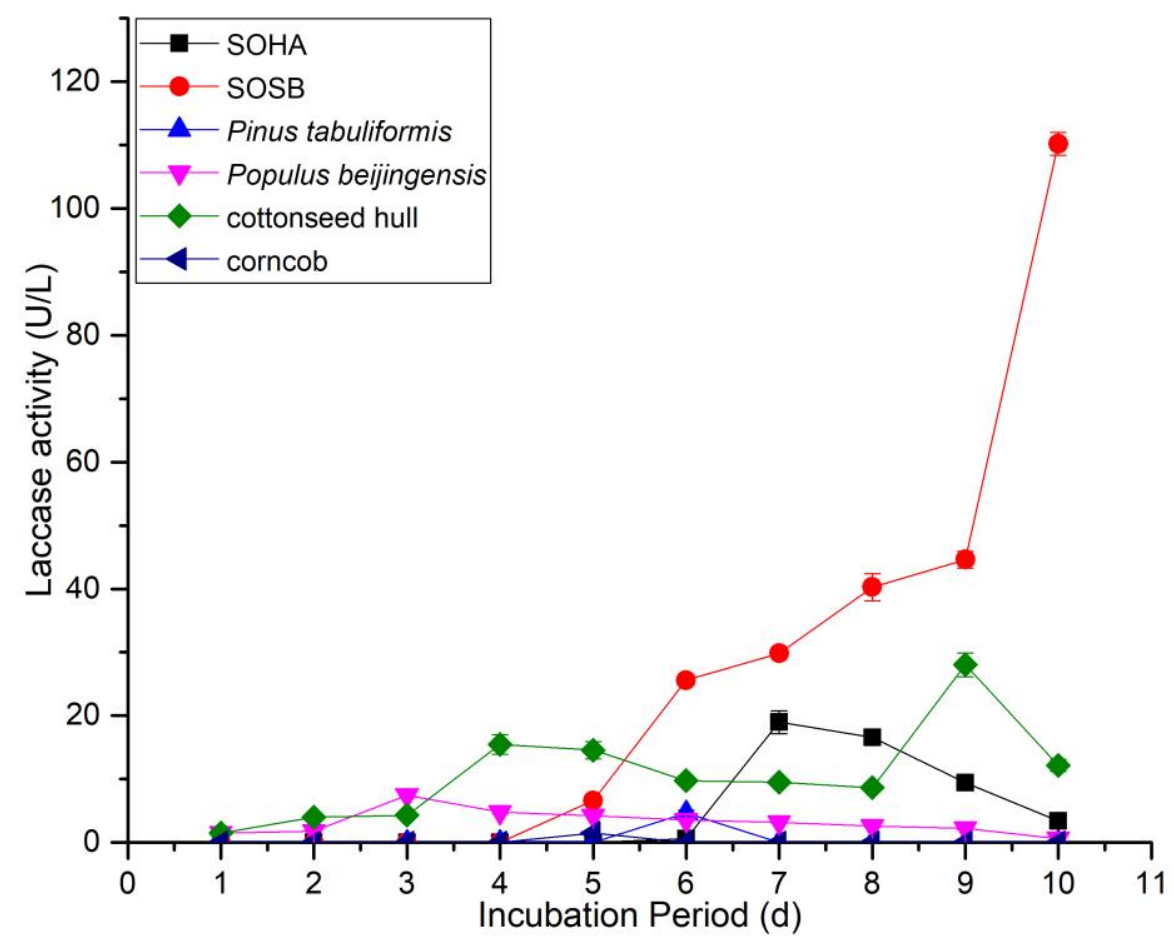

Fig. 2. Laccase activity of Phlebia acerina Han 618 from the SOHA, SOSB, Pinus tabuliformis, Populus beijingensis, cottonseed hull, and corncob on solid-state fermentation. SOHA indicates stalk of Helianthus annuus; SOSB indicates stalk of Sorghum bicolor 
Table 3. Maximum Laccase Activity, Lignocellulosic Biomass, and Occurrence Time of Tested Three White-Rot Fungi

\begin{tabular}{|c|c|c|c|}
\hline $\begin{array}{l}\text { Maximum Laccase } \\
\text { Activity (U/L) }\end{array}$ & Lignocellulosic & Species & Time (Day) \\
\hline $18.98 \pm 1.81$ & SOHA & Phlebia acerina Han 618 & $7^{\text {th }}$ \\
\hline $110.21 \pm 1.82$ & SOSB & Phlebia acerina Han 618 & $10^{\text {th }}$ \\
\hline $4.62 \pm 0.46$ & Pinus tabuliformis & Phlebia acerina Han 618 & $6^{\text {th }}$ \\
\hline $7.43 \pm 0.35$ & Populus beijingensis & Phlebia acerina Han 618 & $3^{\text {rd }}$ \\
\hline $28.03 \pm 1.88$ & Cottonseed hull & Phlebia acerina Han 618 & $9^{\text {th }}$ \\
\hline $1.51 \pm 0$ & Corncob & Phlebia acerina Han 618 & $5^{\text {th }}$ \\
\hline $82.68 \pm 4.39$ & SOHA & $\begin{array}{c}\text { Trametes hirsuta Han } \\
726 \\
\end{array}$ & $10^{\text {th }}$ \\
\hline $183.75 \pm 16.63$ & SOSB & $\begin{array}{c}\text { Trametes hirsuta Han } \\
726\end{array}$ & $8^{\text {th }}$ \\
\hline $4.62 \pm 0.17$ & Pinus tabuliformis & $\begin{array}{c}\text { Trametes hirsuta Han } \\
726\end{array}$ & $7^{\text {th }}$ \\
\hline $12.66 \pm 0.52$ & Populus beijingensis & $\begin{array}{c}\text { Trametes hirsuta Han } \\
726\end{array}$ & $7^{\text {th }}$ \\
\hline $27.43 \pm 1.59$ & Cottonseed hull & $\begin{array}{c}\text { Trametes hirsuta Han } \\
726\end{array}$ & $5^{\text {th }}$ \\
\hline $19.89 \pm 1.31$ & Corncob & $\begin{array}{c}\text { Trametes hirsuta Han } \\
726\end{array}$ & $6^{\text {th }}$ \\
\hline $122.26 \pm 4.57$ & $\mathrm{SOHA}$ & $\begin{array}{c}\text { Coriolopsis trogii Han } \\
751\end{array}$ & $9^{\text {th }}$ \\
\hline $799.03 \pm 40.89$ & SOSB & $\begin{array}{c}\text { Coriolopsis trogii Han } \\
751\end{array}$ & $9^{\text {th }}$ \\
\hline $13.96 \pm 0.46$ & Pinus tabuliformis & $\begin{array}{c}\text { Coriolopsis trogii Han } \\
751\end{array}$ & $1^{\mathrm{st}}$ \\
\hline $18.59 \pm 0.92$ & Populus beijingensis & $\begin{array}{c}\text { Coriolopsis trogii Han } \\
751\end{array}$ & $8^{\text {th }}$ \\
\hline $16.58 \pm 0$ & Cottonseed hull & $\begin{array}{c}\text { Coriolopsis trogii Han } \\
751\end{array}$ & 8th \\
\hline $90.92 \pm 4.01$ & Corncob & $\begin{array}{c}\text { Coriolopsis trogii Han } \\
751\end{array}$ & $8^{\text {th }}$ \\
\hline
\end{tabular}

Laccase activity from Trametes hirsuta Han 726 on SOHA, SOSB, Pinus tabuliformis, Populus beijingensis, cottonseed hull, and corncob was $22.70 \pm 1.66 \mathrm{U} / \mathrm{L}$, $0.90 \pm 0 \mathrm{U} / \mathrm{L}, 0.60 \pm 0 \mathrm{U} / \mathrm{L}, 0.60 \pm 0 \mathrm{U} / \mathrm{L}, 1.21 \pm 0 \mathrm{U} / \mathrm{L}$, and $0.90 \pm 0 \mathrm{U} / \mathrm{L}$ on the $1^{\text {st }}$ day, respectively. Obviously, laccase activity on SOHA was nearly 25.22-fold, 37.83-fold, 37.83-fold, 18.76-fold, and 25.22-fold higher than that on SOSB, Pinus tabuliformis, Populus beijingensis, cottonseed hull, and corncob. The activity of laccase on SOHA decreased from the $1^{\text {st }}$ day, increased from the $4^{\text {th }}$ day, and reached a maximum value of $82.68 \pm 4.39 \mathrm{U} / \mathrm{L}$ on the $10^{\text {th }}$ day (Fig. 3, Table 3). Maximum laccase activity on SOSB was $183.75 \pm 16.63 \mathrm{U} / \mathrm{L}$ on the $8^{\text {th }}$ day (Table 3 ). The level of laccase activity on Pinus tabuliformis was low throughout the whole fermentation process and the maximum laccase activity was merely $4.62 \pm 0.17 \mathrm{U} / \mathrm{L}$ on the $7^{\text {th }}$ day. Maximum laccase activity on Populus beijingensis, cottonseed hull, and corncob was $12.66 \pm 0.52 \mathrm{U} / \mathrm{L}, 27.43 \pm 1.59 \mathrm{U} / \mathrm{L}$, and $19.89 \pm 1.31 \mathrm{U} / \mathrm{L}$, and its corresponding time was $7^{\text {th }}$ day, $6^{\text {th }}$ day, and $5^{\text {th }}$ day (Table 3 ), respectively. Briefly, the maximum laccase activity from T. hirsuta Han 726 appeared on SOSB, nearly 2.22-fold, 39.77-fold, 14.51-fold, 6.70-fold, and 9.24-fold higher than that 
on SOHA, Pinus tabuliformis, Populus beijingensis, cottonseed hull, and corncob, respectively. In other words, the SOSB was more suitable for T. hirsuta Han 726 secreting laccase.

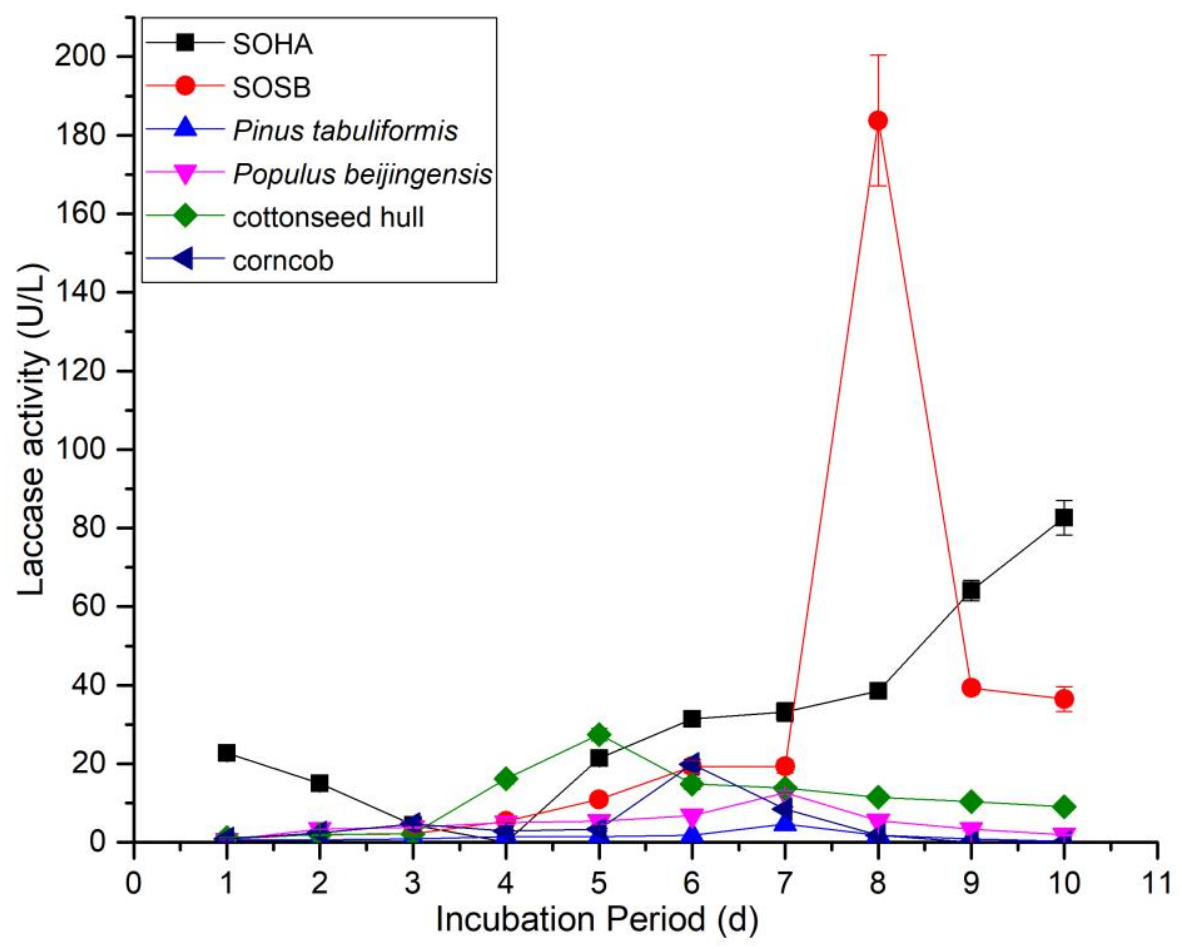

Fig. 3. Laccase activity of Trametes hirsuta Han 726 from the SOHA, SOSB, Pinus tabuliformis, Populus beijingensis, cottonseed hull, and corncob on solid-state fermentation. SOHA indicates stalk of Helianthus annuus; SOSB indicates stalk of Sorghum bicolor

On the $1^{\text {st }}$ day, laccase activity from Coriolopsis trogii Han 751 on SOHA, SOSB, Pinus tabuliformis, Populus beijingensis, cottonseed hull, and corncob was $4.12 \pm 0.17$ $\mathrm{U} / \mathrm{L}, 9.64 \pm 0.60 \mathrm{U} / \mathrm{L}, 13.96 \pm 0.46 \mathrm{U} / \mathrm{L}, 0 \mathrm{U} / \mathrm{L}, 1.21 \pm 0 \mathrm{U} / \mathrm{L}$, and $0.90 \pm 0 \mathrm{U} / \mathrm{L}$, respectively (Fig. 4). The trend of laccase activity on SOHA, SOSB, Populus beijingensis, cottonseed hull, and corncob was similar, and the trend of laccase activity increased first and then decreased after reaching the maximum laccase activity (Fig. 4). Maximum laccase activity on SOHA, SOSB, Populus beijingensis, cottonseed hull, and corncob was $122.26 \pm 4.57$ $\mathrm{U} / \mathrm{L}, 799.03 \pm 40.89 \mathrm{U} / \mathrm{L}, 18.59 \pm 0.92 \mathrm{U} / \mathrm{L}, 16.58 \pm 0 \mathrm{U} / \mathrm{L}$, and $90.92 \pm 4.01 \mathrm{U} / \mathrm{L}$, and its corresponding time was $9^{\text {th }}$ day, $9^{\text {th }}$ day, $8^{\text {th }}$ day, $8^{\text {th }}$ day, and $8^{\text {th }}$ day, respectively (Table 3 ). Different from the trend of laccase activity on other lignocellulosic biomasses, the laccase activity on Pinus tabuliformis reached its maximum on the $1^{\text {st }}$ day, which was only $13.96 \pm 0.46 \mathrm{U} / \mathrm{L}$. Then the laccase activity began to decline, and no laccase activity could be detected after the $7^{\text {th }}$ day (Table 3, Fig. 4). In conclusion, maximum laccase activity from C. trogii Han 751 appeared on SOSB, nearly 6.54-fold, 57.24-fold, 42.98-fold, 48.19fold, and 8.79-fold higher than that on SOHA, Pinus tabuliformis, Populus beijingensis, cottonseed hull, and corncob, respectively. Thus, the SOSB was more suitable for C. trogii Han 751 to secret laccase. 


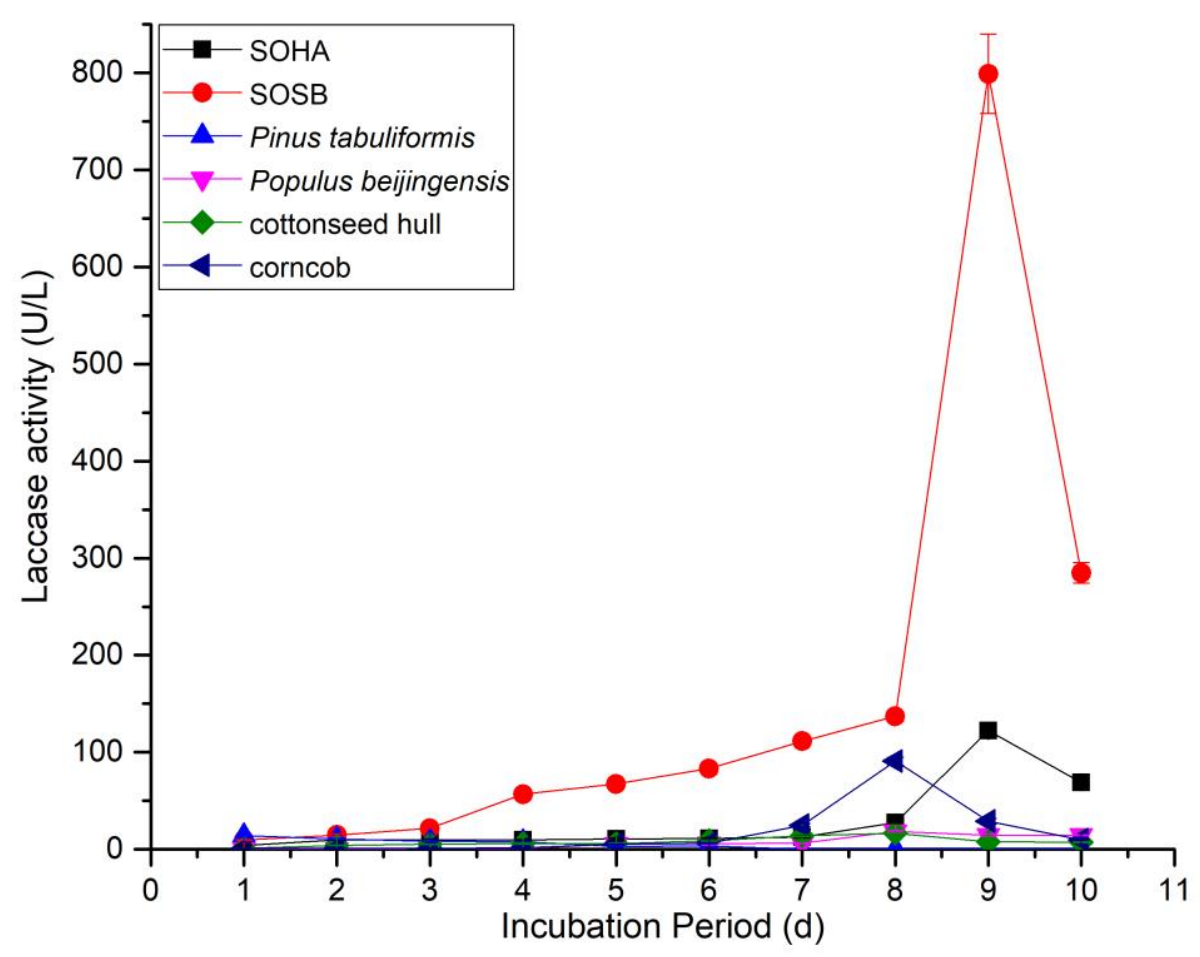

Fig. 4. Laccase activity of Coriolopsis trogii Han 751 from the SOHA, SOSB, Pinus tabuliformis, Populus beijingensis, cottonseed hull, and corncob on solid-state fermentation. SOHA indicates stalk of Helianthus annuus; SOSB indicates stalk of Sorghum bicolor

\section{Comparison of Laccase Activity from Tested Three White-Rot Fungi}

In terms of laccase activity on SOHA, the laccase activity on the $1^{\text {st }}$ day was not detected by Phlebia acerina Han 618, and the value from Trametes hirsuta Han 726 was higher than that from Coriolopsis trogii Han 751. That seemed to indicate that SOHA was suitable for the rapid secretion of laccase by $T$. hirsuta Han 726. However, the maximum laccase activity from $C$. trogii Han 751 was nearly 6.44-fold and 1.48-fold higher than that from $P$. acerina Han 618 and T. hirsuta Han 726 (Table 3), respectively. In other words, SOHA was suitable for $C$. trogii Han 751 secreting laccase based on the maximum laccase activity. Laccase activity from $P$. acerina Han 618, T. hirsuta Han 726, and C. trogii Han 751 on SOSB on the $1^{\text {st }}$ day expressed at low level and was $0 \mathrm{U} / \mathrm{L}, 0.90 \pm 0 \mathrm{U} / \mathrm{L}$, and 9.64 $\pm 0.60 \mathrm{U} / \mathrm{L}$, respectively. But the maximum laccase activity on SOSB was higher than that on other lignocellulosic biomasses (Figs. 2 through 4), and the value was $110.21 \pm 1.82$ U/L from $P$. acerina Han 618, $183.75 \pm 16.63$ U/L from T. hirsuta Han 726, and 799.03 \pm 40.89 U/L from C. trogii Han 751 (Table 3). Thus, SOSB was suitable for the three tested white-rot fungi to secret laccase. In terms of laccase activity on Pinus tabuliformis and Populus beijingensis, P. acerina Han 618, T. hirsuta Han 726, and C. trogii Han 751 showed a low level of laccase activity, and the maximum values were $4.62 \pm 0.46 \mathrm{U} / \mathrm{L}$ and $7.43 \pm 0.35 \mathrm{U} / \mathrm{L}, 4.62 \pm 0.17 \mathrm{U} / \mathrm{L}$ and $12.66 \pm 0.52 \mathrm{U} / \mathrm{L}$, and $13.96 \pm 0.46 \mathrm{U} / \mathrm{L}$ and $18.59 \pm$ $0.92 \mathrm{U} / \mathrm{L}$. Obviously, none of the three tested strains were suitable for secreting laccase on Pinus tabuliformis and Populus beijingensis. Similarly, cottonseed hull was not suitable 
for testing white-rot fungi secreting laccase due to the low level of laccase activity (Figs. 2 through 4). For corncob, P. acerina Han 618, T. hirsuta Han 726, and C. trogii Han 751 showed different trends of laccase activity. Phlebia acerina Han 618 laccase activity could only be detected on the $5^{\text {th }}$ day, $T$. hirsuta Han 726 laccase activity could be detected before 8 days, and the maximum value of laccase activity was $19.89 \pm 1.31 \mathrm{U} / \mathrm{L}$, while $C$. trogii Han 751 laccase activity could be detected during the whole fermentation stage and the maximum value of laccase activity was $90.92 \pm 4.01 \mathrm{U} / \mathrm{L}$. Interestingly, laccase activity from $C$. trogii Han 751 on different lignocellulosic biomasses was higher than that from $P$. acerina Han 618 or $T$. hirsuta Han 726. Thus, the capacity of $C$. trogii Han 751 secreting laccase was superior to that of P. acerina Han 618 and T. hirsuta Han 726.

The maximum value of laccase from Coriolopsis rigida on barley bran was around $3 \times 10^{5} \mathrm{nkat} / \mathrm{L}$, and the result showed that the capacity of Coriolopsis rigida secreting laccase by was excellent (Gómez et al. 2005; Alcántara et al. 2007). Similarly, the maximum laccase activity from $C$. trogii Han 751 on SOSB in the present study was 799.03 $\pm 40.89 \mathrm{U} / \mathrm{L}$, and the result also showed a strong ability of laccase secretion for $C$. trogii Han 751. The laccase activity of Pleurotus ostreatus IBB 8, P. ostreatus 2175, P. tuberregium IBB 624, Lentinus edodes IBB 123, L. edodes IBB 363, and L. edodes IBB 369 fermentation on tree leaves or wheat straw through conventional solid-state fermentation was $7 \pm 0.7$ or $7 \pm 0.8$ U/flask, $15 \pm 1.4$ or $12 \pm 1.2$ U/flask, $20 \pm 1.8$ or $10 \pm$ 1.0 U/flask, $57 \pm 4.7$ or $20 \pm 1.5$ U/flask, $52 \pm 4.9$ or $55 \pm 5.1$ U/flask, and $7 \pm 0.7$ or $38 \pm$ 4.0 U/flask, respectively (Elisashvili et al. 2008). The values of the highest laccase activity were $386 \mathrm{U} / \mathrm{L}$ for $T$. trogii incubated in a medium containing pulverized apricot seed shell in submerged fermentation (Birhanli and Yeşilada 2013).

The laccase activity of $P$. ostreatus CY 568 wild strain on sawdust and corncob via solid-state fermentation ranged from $36.77 \pm 2.17 \mathrm{U} / \mathrm{L}$ to $353.83 \pm 11.94 \mathrm{U} / \mathrm{L}$ and $9.64 \pm$ $0.52 \mathrm{U} / \mathrm{L}$ to $440.73 \pm 8.36 \mathrm{U} / \mathrm{L}$, and the laccase activity of $P$. ostreatus CCEF 99 cultivated strain on sawdust and corncob via solid-state fermentation ranged from $67.21 \pm 3.67 \mathrm{U} / \mathrm{L}$ to $548.72 \pm 19.59 \mathrm{U} / \mathrm{L}$ and $16.88 \pm 1.51 \mathrm{U} / \mathrm{L}$ to $286.12 \pm 25.80 \mathrm{U} / \mathrm{L}$, respectively (Han $e t$ al. 2020b). The laccase production of $P$. ostreatus CCEF 89 in cottonseed hull, corncob, and poplar wood under submerged fermentation ranged from $61.38 \pm 4.09 \mathrm{U} / \mathrm{L}$ to 748.24 $\pm 9.53 \mathrm{U} / \mathrm{L}, 26.12 \pm 2.28 \mathrm{U} / \mathrm{L}$ to $699.12 \pm 44.91 \mathrm{U} / \mathrm{L}$, and $3.32 \pm 0.30 \mathrm{U} / \mathrm{L}$ to $509.75 \pm$ $15.43 \mathrm{U} / \mathrm{L}$, and the maximum laccase activity for P. ostreatus strain CY 568 obtained from cottonseed hull, corncob, and poplar wood was 902.92 $\pm 25.42 \mathrm{U} / \mathrm{L}, 611.71 \pm 24.21 \mathrm{U} / \mathrm{L}$, and 590.72 $\pm 14.98 \mathrm{U} / \mathrm{L}$, respectively (An et al. 2020). Overall, the presence of cottonseed hull was conducive to secreting laccase by $P$. ostreatus strains in submerged fermentation or on solid-state fermentation. But the presence of cottonseed hull was disadvantageous for secreting laccase from Phlebia acerina Han 618, Trametes hirsuta Han 726, and Coriolopsis trogii Han 751 (Figs. 2 through 4). Laccase activity of four basidiomycete fungi fermentation on Populus beijingensis, Firmiana platanifolia, straw of Sorghum bicolor, and straw of Oryza sativa was investigated, and the results showed that different species of fungi had a preference in lignocellulosic residues (Han et al. 2021a). Among these, Cerrena unicolor Han 849 preferred Firmiana platanifolia, while Lenzites betulinus Han 851 and Auricularia heimuer Han 1333 showed a more obvious preference for straw of Oryza sativa (Han et al. 2021a). The presence of cottonseed hull and Populus beijingensis were useful for accelerating the rate of laccase production of $P$. ostreatus $\mathrm{CY}$ 568, while the presence of Toona sinensis, cottonseed hull, and corncob were useful for accelerating the rate of laccase production for Ganoderma lingzhi Han 500 (An et al. 2021). In the present study, three species, P. acerina Han 618, T. hirsuta Han 726, and C. trogii 
Han 751 showed consistency in preference of lignocellulosic biomass, and the presence of SOSB was more suitable for their secreting laccase. The laccase secreting ability of $C$. unicolor Han 849 was stronger than those of L. betulinus Han 851, Stropharia rugosoannulata Han 1321, and A. heimuer Han 1333 based on analyses of their laccase activities on different lignocellulosic residues (Han et al. 2021a). In the present study, the capacity of secreting laccase of $C$. trogii Han 751 was superior to that of $P$. acerina Han 618 and T. hirsuta Han 726. Based on this, the optimization of fermentation conditions and analysis of enzymatic properties of $C$. trogii Han 751 will be the next research work of the current authors.

\section{CONCLUSIONS}

1. Three white-rot fungi, Phlebia acerina Han 618, Trametes hirsuta Han 726, and Coriolopsis trogii Han 751, isolated from their native habitat in North China, were identified based on the sequence of internal transcribed spacer (ITS) and were preliminarily screened for the ability of laccase-producing by guaiacol selection medium.

2. Three species, P. acerina Han 618, T. hirsuta Han 726, and C. trogii Han 751 showed consistency in preference of lignocellulosic biomass, and the presence of SOSB was more suitable for their secreting laccase.

3. The capacity of laccase secretion from different species used in the present study was significantly different. The capacity of secreting laccase of $C$. trogii Han 751 was superior to that of $P$. acerina Han 618 and T. hirsuta Han 726.

\section{ACKNOWLEDGMENTS}

The authors gratefully acknowledge the financial support of the National Natural Science Foundation of China (Grant No. 31900009), Special Project of Cultivating Scientific and Technological Innovation Ability of College and Middle School Students (Grant No. 2021H100404), the Fundamental Research Funds for the Universities in Hebei Province (Grant No. JYQ202101), and National Innovation and Entrepreneurship Training Program for College Students (Grant No. 202110100003).

\section{REFERENCES CITED}

Alcántara, T., Gómez, J., Pazos, M., and Sanromán, M. A. (2007). "Enhanced production of laccase in Coriolopsis rigida grown on barley bran in flask or expanded-bed bioreactor," World J. Microb. Biot. 23(8), 1189-1194. DOI: 10.1007/s11274-0069334-y

An, Q., Han, M., Wu, X., Si, J., Cui, B., Dai, Y., and Wu, B. (2016). "Laccase production among medicinal mushrooms from the Genus Flammulina (Agaricomycetes) under different treatments in submerged fermentation," Int. J. Med. Mushrooms 18(11), 1049-1059. DOI: 10.1615/IntJMedMushrooms.v18.i11.90

An, Q., Li, C., Yang, J., Chen, S., Ma, K., Wu, Z., Bian, L., and Han, M. (2021). 
"Evaluation of laccase production by two white-rot fungi using solid-state fermentation with different agricultural and forestry residues," BioResources 16(3), 5287-5300. DOI: 10.15376/biores.16.3.5287-5300

An, Q., Ma, H., Han, M., Si, J., and Dai, Y. (2018). "Effects of different induction media as inducers on laccase activities of Pleurotus ostreatus strains in submerged fermentation," BioResources 13(1), 1143-1156. DOI: 10.15376/biores.13.1.11431156

An, Q., Qiao, J., Bian, L., Han, M., Yan, X., Liu, Z., and Xie, C. (2020). “Comparative study on laccase activity of white rot fungi under submerged fermentation with different lignocellulosic wastes," BioResources 15(4), 9166-9179. DOI: 10.15376/biores. 15.4.9166-9179

Atilano-Camino, M. M., Álvarez-Valencia, L. H., García-González, A., and GarcíaReyes, R. (2020). “Improving laccase production from Trametes versicolor using lignocellulosic residues as cosubstrates and evaluation of enzymes for blue wastewater biodegradation," J. Environ. Manage. 275, article no. 111231. DOI: 10.1016/j.jenvman.2020.111231

Avelar, M., Olvera, C., Aceves-Zamudio, D., Folch, J. L., and Ayala, M. (2017). "Recombinant expression of a laccase from Coriolopsis gallica in Pichia pastoris using a modified alpha-factor preproleader," Protein Expres. Purif. 136, 14-19. DOI: 10.1016/j.pep.2017.06.001

Bettin, F., Cousseau, F., Martins, K., Zaccaria, S., Girardi, V., da Silveira, M. M., and Dillon, A. (2019). "Effects of $\mathrm{pH}$, temperature and agitation on the decolourisation of dyes by laccase-containing enzyme preparation from Pleurotus sajor-caju," Braz. Arch. Biol. Technol. 62, article no. e19180338. DOI: 10.1590/1678-43242019180338

Bilal, M., Noreen, S., Asgher, M., and Parveen, S. (2021). "Development and characterization of cross-linked laccase aggregates (Lac-CLEAs) from Trametes versicolor IBL-04 as ecofriendly biocatalyst for degradation of dye-based environmental pollutants," Environ. Technol. Inno. 21, article no. 101364. DOI: 10.1016/j.eti.2021.101364

Birhanli, E., and Yeşilada, Ö. (2013). "The utilization of lignocellulosic wastes for laccase production under semisolid-state and submerged fermentation conditions," Turk. J. Biol. 37(4), 450-456. DOI: 10.3906/biy-1211-25

Coria-Oriundo, L. L., Battaglini, F., and Wirth, S. A. (2021). "Efficient decolorization of recalcitrant dyes at neutral/alkaline $\mathrm{pH}$ by a new bacterial laccase-mediator system," Ecotox. Environ. Saf. 217, article no. 112237. DOI: 10.1016/j.ecoenv.2021.112237

Darwesh, O. M., El-Maraghy, S. H., Abdel-Rahman, H. M., and Zaghloul, R. A. (2020). "Improvement of paper wastes conversion to bioethanol using novel cellulose degrading fungal isolate," Fuel 262, article no. 116518. DOI:

10.1016/j.fuel.2019.116518

Elisashvili, V., Penninckx, M., Kachlishvili, E., Tsiklauri, N., Metreveli, E., Kharziani, T., and Kvesitadze, G. (2008). "Lentinus edodes and Pleurotus species lignocellulolytic enzymes activity in submerged and solid-state fermentation of lignocellulosic wastes of different composition," Bioresour. Technol. 99(3), 457-462. DOI: 10.1016/j.biortech.2007.01.011

Felsenstein, J. (1985). "Confidence limits on phylogenetics: An approach using the bootstrap," Evolution 39(4), 783-791. DOI: 10.2307/2408678

Fonseca, M. I., Molina, M. A., Winnik, D. L., Busi, M. V., Fariña, J. I., Villalba, L. L., 
and Zapata, P. D. (2018). "Isolation of a laccase-coding gene from the lignindegrading fungus Phlebia brevispora BAFC 633 and heterologous expression in Pichia pastoris," J. Appl. Microbiol. 124(6), 1454-1468. DOI: 10.1111/jam.13720

Fonseca, M. I., Ramos-Hryb, A. B., Fariña, J. I., Afanasiuk, S. S. S., Villalba, L. L., and Zapata, P. D. (2014). "Effect of chemical and metallic compounds on biomass, mRNA levels and laccase activity of Phlebia brevispora BAFC 633," World J. Microbiol. Biotechnol. 30(8), 2251-2262. DOI: 10.1007/s11274-014-1646-8

Gaikwad, A. and Meshram, A. (2020). "Effect of particle size and mixing on the laccasemediated pretreatment of lignocellulosic biomass for enhanced saccharification of cellulose," Chem. Eng. Commun. 207(12), 1696-1706. DOI:

10.1080/00986445.2019.1680364

Glazunova, O. A., Shakhova, N. V., Psurtseva, N. V., Moiseenko, K. V., Kleimenov, S. Y., and Fedorova, T. V. (2018). "White-rot basidiomycetes Junghuhnia nitida and Steccherinum bourdotii: Oxidative potential and laccase properties in comparison with Trametes hirsuta and Coriolopsis caperata," PloS One 13(6), article no. e0197667. DOI: 10.1371/journal.pone.0197667

Gómez, J., Pazos, M., Couto, S. R., and Sanromán, M. A. (2005). “Chestnut shell and barley bran as potential substrates for laccase production by Coriolopsis rigida under solid-state conditions," J. Food Eng. 68(3), 315-319. DOI:

10.1016/j.jfoodeng.2004.06.005

Han, M., Chen, Y., Shen, L., Song, J., Vlasák, J., Dai, Y., and Cui, B. (2016). "Taxonomy and phylogeny of the brown-rot fungi: Fomitopsis and its related genera," Fungal Divers. 80(1), 343-373. DOI: 10.1007/s13225-016-0364-y

Han, M., An, Q., Fu, W., Cheng, X., Bu, T., and Li, W. (2020a). "Morphological characteristics and phylogenetic analyses reveal Antrodia yunnanensis sp. nov. (Polyporales, Basidiomycota) from China," Phytotaxa 460(1), 1-11. DOI: 10.11646/phytotaxa.460.1.1

Han, M., An, Q., He, S., Zhang, X.., Zhang, M., Gao, X., Wu, Q., and Bian, L. (2020b). "Solid-state fermentation on poplar sawdust and corncob wastes for lignocellulolytic enzymes by different Pleurotus ostreatus strains," BioResources 15(3), 4982-4995. DOI: 10.15376/biores.15.3.4982-4995

Han, M., An, Q., Ma, K., An, W., Hao, W., Liu, M., Shi, W., Yang, J., and Bian, L. (2021a). "A comparative study on the laccase activity of four Basidiomycete fungi with different lignocellulosic residues via solid-state fermentation," BioResources 16(2), 3017-3031. DOI: 10.15376/biores.16.2.3017-3031

Han, M., Bian, L., Zhang, Y., Zhu, M., and An, Q. (2021b). "Pseudolagarobasidium baiyunshanense sp. nov. from China inferred from morphological and sequence analyses," Phytotaxa 483(2), 169-176. DOI: 10.11646/phytotaxa.483.2.9

Han, M., Yang, J., Liu, Z., Wang, C., Chen, S., Han, N., Hao, W., An, Q., and Dai, Y. (2021c). "Evaluation of laccase activities by three newly isolated fungal species in submerged fermentation with single or mixed lignocellulosic wastes," Front. Microbiol. 12, article no. 682679. DOI: 10.3389/fmicb.2021.682679

Hu, J., Zhang, Y., Xu, Y., Sun, Q., Liu, J., Fang, W., Xiao, Y., Kües, U., and Fang, Z. (2021). "Gongronella sp. w5 elevates Coprinopsis cinerea laccase production by carbon source syntrophism and secondary metabolite induction," Appl. Microbiol. Biotechnol. 103(1), 411-425. DOI: 10.1007/s00253-018-9469-4

Huang, L., Sun, N., Ban, L., Wang, Y., and Yang, H. (2019). “Ability of different edible fungi to degrade crop straw," AMB Expr. 9, article no. 4. DOI: 10.1186/s13568-018- 
0731-Z

Huang, W., Zhang, W., Gan, Y., Yang, J., and Zhang, S. (2020). "Laccase immobilization with metal-organic frameworks: Current status, remaining challenges and future perspectives," Crit. Rev. Env. Sci. Tec. Early Access. DOI: 10.1080/10643389.2020.1854565

Janusz, G., Czuryło, A., Frąc, M., Rola, B., Sulej, J., Pawlik, A., Siwulski, M., and Rogalski, J. (2015). "Laccase production and metabolic diversity among Flammulina velutipes strains,” World J. Microb. Biot. 31(1), 121-133. DOI: 10.1007/s11274-0141769-y

Janusz, G., Sulej, J., Jaszek, M., and Osinska-Jaroszuk, M. (2016). "Effect of different wavelengths of light on laccase, cellobiose dehydrogenase, and proteases produced by Cerrena unicolor, Pycnoporus sanguineus, and Phlebia lindtneri," Acta Biochim. Pol. 63(2), 223-228. DOI: 10.18388/abp.2015_1235

Kaneko, S., Cheng, M., Murai, H., Takenaka, S., Murakami, S., and Aoki, K. (2009). "Purification and characterization of an extracellular laccase from Phlebia radiata strain BP-11-2 that decolorizes fungal melanin," Biosci. Biotechnol. Biochem. 73(4), 939-942. DOI: $10.1271 / \mathrm{bbb} .80740$

Kołodziejczak-Radzimska, A., Budna, A., Ciesielczyk, F., Moszyński, D., and Jesionowski, T. (2020). "Laccase from Trametes versicolor supported onto mesoporous $\mathrm{Al}_{2} \mathrm{O}_{3}$ : Stability tests and evaluations of catalytic activity," Process Biochem. 95, 71-80. DOI: 10.1016/j.procbio.2020.05.008

Li, H., Dou, M., Wang, X., Guo, N., Kou, P., Jiao, J., and Fu, Y. (2021). “Optimization of cellulase production by a novel endophytic fungus Penicillium oxalicum R4 isolated from Taxus cuspidate," Sustainability 13(11), Article Number 6006. DOI: $10.3390 / \mathrm{su} 13116006$

Mejía-Otálvaro, F., Merino-Restrepo, A., and Hormaza-Anaguano, A. (2021). "Evaluation of a Trametes pubescens laccase concentrated extract on allura red AC decolorization without the addition of synthetic mediators," J. Environ. Manage. 285, article no. 112117. DOI: 10.1016/j.jenvman.2021.112117

Moreira, J. R., Romeiro, V., Fuss, S., Kraxner, F., and Pacca, S. A. (2016). "BECCS potential in Brazil: Achieving negative emissions in ethanol and electricity production based on sugar cane bagasse and other residues," Appl. Energy 179, 55-63. DOI: 10.1016/j.apenergy.2016.06.044

Navada, K. K., and Kulal, A. (2021). "Kinetic characterization of purified laccase from Trametes hirsuta: A study on laccase catalyzed biotransformation of 1,4-dioxane," Biotechnol. Lett. 43(3), 613-626. DOI: 10.1007/s10529-020-03038-1

Nishida, T., Kashino, Y., Mimura, A., and Takahara, Y. (1988). "Lignin biodegradation by wood-rotting fungi: I. Screening of lignin-degrading fungi," Mokuzai Gakkaishi 34, 530-536.

Ottoni, C., Simões, M. F., Fernandes, S., Santos, C. R., and Lima, N. (2016). "High laccase expression by Trametes versicolor in a simulated textile effluent with different carbon sources and pHs," Int. J. Env. Res. Pub. He. 13(8), article no. 778. DOI: $10.3390 /$ ijerph13080778

Palazzolo, M. A., Postemsky, P. D., and Kurina-Sanz, M. (2019). "From agro-waste to tool: Biotechnological characterization and application of Ganoderma lucidum E47 laccase in dye decolorization," 3 Biotech 9(6), article no. 213. DOI: 10.1007/s13205019-1744-2

Pinar, O., Tamerler, C., and Karatas, A. Y. (2017). "Heterologous expression and 
characterization of a high redox potential laccase from Coriolopsis polyzona MUCL 38443," Turk. J. Biol. 41(2), 278-291. DOI: 10.3906/biy-1605-51

Rodrigues, E. M., Karp, S. G., Malucelli, L. C., Helm, C. V., and Alvarez, T. M. (2019). "Evaluation of laccase production by Ganoderma lucidum in submerged and solidstate fermentation using different inducers," J. Basic Microb. 59(8), 784-791. DOI: 10.1002/jobm.201900084

Sharma, A., Jain, K. K., Srivastava, A., Shrivastava, B., Thakur, V. V., Jain, R. K., and Kuhad, R. C. (2019). "Potential of in situ SSF laccase produced from Ganoderma lucidum RCK 2011 in biobleaching of paper pulp," Bioproc. Biosyst. Eng. 42(3), 367377. DOI: 10.1007/s00449-018-2041-X

Shokri, Z., Seidi, F., Karami, S., Li, C., Saeb, M. R., and Xiao, H. (2021). "Laccase immobilization onto natural polysaccharides for biosensing and biodegradation," Carbohydr. Polym. 262, article no. 117963. DOI: 10.1016/j.carbpol.2021.117963

Soccol, C. R., da Costa, E. S. F., Letti, L. A. J., Karp, S. G., Woiciechowski, A. L., and de Souza Vandenberghe, L. P. (2017). "Recent developments and innovations in solid state fermentation," Biotechnol. Res. Innov. 1(1), 52-71. DOI:

10.1016/j.biori.2017.01.002

Songulashvili, G., Flahaut, S., Demarez, M., Tricot, C., Bauvois, C., Debaste, F., and Penninckx, M. J. (2016). "High yield production in seven days of Coriolopsis gallica 1184 laccase at $50 \mathrm{~L}$ scale; enzyme purification and molecular characterization," Fungal Biol. 120(4), 481-488. DOI: 10.1016/j.funbio.2016.01.008

Steudler, S., and Bley, T. (2015). "Better one-eyed than blind - Challenges and opportunities of biomass measurement during solid-state fermentation of basidiomycetes," Adv. Biochem. Eng. Biotechnol. 149, 223-252.DOI: 10.1007/10_2014_300

Sun, K., Cheng, X., Yu, J., Chen, L., Wei, J., Chen, W., Wang, J., Li, S., Liu, Q., and Si, Y. (2020). "Isolation of Trametes hirsuta La-7 with high laccase-productivity and its application in metabolism of 17 beta-estradiol," Environ. Pollut. 263, article no. 114381. DOI: 10.1016/j.envpol.2020.114381

Sun, K., Hong, D., Liu, J., Latif, A., Li, S., Chu, G., Qin, W., and Si, Y. (2021a). "Trametes versicolor laccase-assisted oxidative coupling of estrogens: Conversion kinetics, linking mechanisms, and practical applications in water purification," Sci. Total Environ. 782, article no. 146917. DOI: 10.1016/j.scitotenv.2021.146917

Sun, K., Li, S., Si, Y., and Huang, Q. (2021b). “Advances in laccase-triggered anabolism for biotechnology applications," Crit. Rev. Biotechnol. 41(7), 969-993. DOI: 10.1080/07388551.2021.1895053

Swofford, D. L. (2002). PAUP*: Phylogenetic Analysis Using Parsimony (*And Other Methods). Version 4.0b10, Sinauer Associates, Sunderland, MA, USA. DOI: 10.1111/j.0014-3820.2002.tb00191.x

Unuofin, J. O., Okoh, A. I., and Nwodo, U. U. (2019). "Aptitude of oxidative enzymes for treatment of wastewater pollutants: A laccase perspective," Molecules 24(11), article no. 2064. DOI: 10.3390/molecules 24112064

White, T. J., Bruns, T. D., Lee, S. B., and Taylor, J. W. (1990). “Amplification and direct sequencing of fungal ribosomal RNA genes for phylogenetics," in: PCR Protocols: A Guide to Methods and Applications; M. A. Innis, D. H. Gelfand, J. J. Sninsky, T. J. White (eds.), Academic Press, San Diego, CA, USA, pp. 315-322.

Wulandari, R., Lotrakul, P., Punnapayak, H., Amirta, R., Kim, S. W., and Prasongsuk, S. (2021). "Toxicity evaluation and biodegradation of phenanthrene by laccase from Trametes polyzona PBURU 12," 3 Biotech 11(1), article no. 32. DOI: 
$10.1007 / \mathrm{s} 13205-020-02556-\mathrm{Z}$

Xu, X., Feng, L., Han, Z., Luo, S., Wu, A., and Xie, J. (2016). "Selection of high laccaseproducing Coriolopsis gallica strain T906: Mutation breeding, strain characterization, and features of the extracellular laccases," J. Microbiol. Biotechnol. 26(9), 15701578. DOI: $10.4014 /$ jmb.1604.04011

Yin, Q., Zhou, G., Peng, C., Zhang, Y., Kües, U., Liu, J., Xiao, Y., and Fang, Z. (2019). "The first fungal laccase with an alkaline $\mathrm{pH}$ optimum obtained by directed evolution and its application in indigo dye decolorization," AMB Expr. 9(1), article no. 151. DOI: 10.1186/s13568-019-0878-2

Yousef, S., Eimontas, J., Zakarauskas, K., Striūgas, N., and Mohamed, A. (2021a). “A new strategy for using lint-microfibers generated from clothes dryer as a sustainable source of renewable energy," Sci. Total Environ. 762, article no. 143107. DOI: 10.1016/j.scitotenv.2020.143107

Yousef, S., Kuliešienè, N., Sakalauskaite, S., Nenartavičius, T., and Daugelavičius, R. (2021b). "Sustainable green strategy for recovery of glucose from end-of-life euro banknotes," Waste Manag. 123, 23-32. DOI: 10.1016/j.wasman.2021.01.007

Zerva, A., Simić, S., Topakas, E., and Nikodinovic-Runic, J. (2019). “Applications of microbial laccases: Patent review of the past decade (2009-2019)," Catalysts 9(12), article no. 1023. DOI: $10.3390 /$ catal9121023

Zhang, J., Ke, W., and Chen, H. (2020). "Enhancing laccase production by white-rot fungus Trametes hirsuta SSM-3 in co-culture with yeast Sporidiobolus pararoseus SSM-8," Prep. Biochem. Biotech. 50(1), 10-17. DOI: 10.1080/10826068.2019.1655764

Zhang, Y., Wu, Y., Yang, X., Yang, E., Xu, H., Chen, Y., Chagan, I., and Yan, J. (2021). "Alternative splicing of heat shock transcription factor 2 regulates expression of the laccase gene family in response to copper in Trametes trogii," Appl. Environ. Microbiol. 87(8), article no. e00055-21. DOI: 10.1128/AEM.00055-21

Zhou, J., Yang, T., Mei, Y., Kang, J., and Dai, C. (2014). "Laccase production by Phomopsis liquidambari B3 cultured with food waste and wheat straw as the main nitrogen and carbon sources," J. Air Waste Manage. 64(10), 1154-1163. DOI: 10.1080/10962247.2014.930077

Zhou, W., Zhang, W., and Cai, Y. (2021). "Laccase immobilization for water purification: A comprehensive review," Chem. Eng. J. 403, article no. 126272. DOI: 10.1016/j.cej.2020.126272

Article submitted: October 5, 2021; Peer review completed: November 6, 2021; Revised version received and accepted: January 8, 2022; Published: January 14, 2022.

DOI: $10.15376 /$ biores.17.1.1533-1550 